\title{
Challenges in implementing and maintaining osteoporosis therapy
}

This article was published in the following Dove Press journal:

International Journal of Women's Health

13 August 2014

Number of times this article has been viewed

\author{
Ankita Modi' \\ Shiva Sajjan' \\ Sampada Gandhi \\ 'Center for Observational and Real- \\ World Evidence, Merck \& Co., Inc., \\ Whitehouse Station, NJ, USA; \\ ${ }^{2}$ School of Public Health, Rutgers \\ University, Piscataway, NJ, USA
}

\begin{abstract}
In the United States, an estimated $19 \%$ of older men and 30\% of older women are at elevated risk of osteoporotic fracture and considered to be eligible for treatment. The burden of osteoporosis is similar in Europe and is projected to rise worldwide, with aging populations and increasing fracture rates accompanying urbanization. Notwithstanding its high prevalence, osteoporosis is often underdiagnosed and undertreated. Moreover, even when the diagnosis is made and the decision is taken to treat, there are remaining challenges in implementing therapy for osteoporosis. Several patient populations are particularly challenging for clinicians to treat and require further study with regard to osteoporosis therapy. These include the very elderly, who face challenges relating to adherence; men, in whom osteoporosis remains underrecognized; patients with glucocorticoid-induced osteoporosis or renal impairment, who are at increased risk of fracture; patients with preexisting gastrointestinal problems who cannot tolerate existing orally administered osteoporosis therapies; and high-risk patients who show inadequate response to therapy. Moreover, poor adherence and poor persistence with osteoporosis medications are common and result in an increased risk of fracture, higher medical costs, and increased hospitalizations. Once the decision to institute therapy is made, patient education about osteoporosis and fracture risk should be provided. This is particularly important for men, who may not be aware that osteoporosis can be a concern. Secondary prevention programs, including fracture liaison services and bone therapy groups, can help to improve adherence to therapy. Further study is needed to guide the treatment of men, the very elderly, patients with glucocorticoid-induced osteoporosis and renal impairment, high-risk patients not well-controlled despite therapy, and patients with preexisting gastrointestinal conditions. Moreover, therapies are needed that are viewed as effective and safe by both physicians and patients, and as convenient to take by patients.
\end{abstract}

Keywords: adherence, chronic kidney disease, glucocorticoid-induced osteoporosis, fracture

\section{Introduction}

An estimated $30 \%$ of women and $19 \%$ of men 50 years and older in the USA are at elevated risk of osteoporotic (fragility) fracture and are considered to be eligible for pharmacologic treatment. ${ }^{1}$ The burden of osteoporosis is similar in Europe and is projected to rise around the globe, with aging populations and increasing fracture rates accompanying urbanization. ${ }^{2,3}$ An estimated 9 million new osteoporotic fractures occurred worldwide in the year 2000 (Figure 1); these included 1.6 million hip fractures, 1.7 million forearm fractures, and 1.4 million clinical vertebral fractures, roughly half of which occurred in North America and Europe. ${ }^{4}$ In Europe alone, the direct medical costs of osteoporotic fractures in 2005 were $€ 31.7$ billion, to which must be added the
Correspondence: Ankita Modi World Evidence, Merck \& Co, Inc, One Merck Drive, PO Box 100 , WS2E-13, Whitehouse Station, NJ 08889-0I00, USA

Tel +l 9084236162

Email ankita.modi@merck.com 


\section{Number}
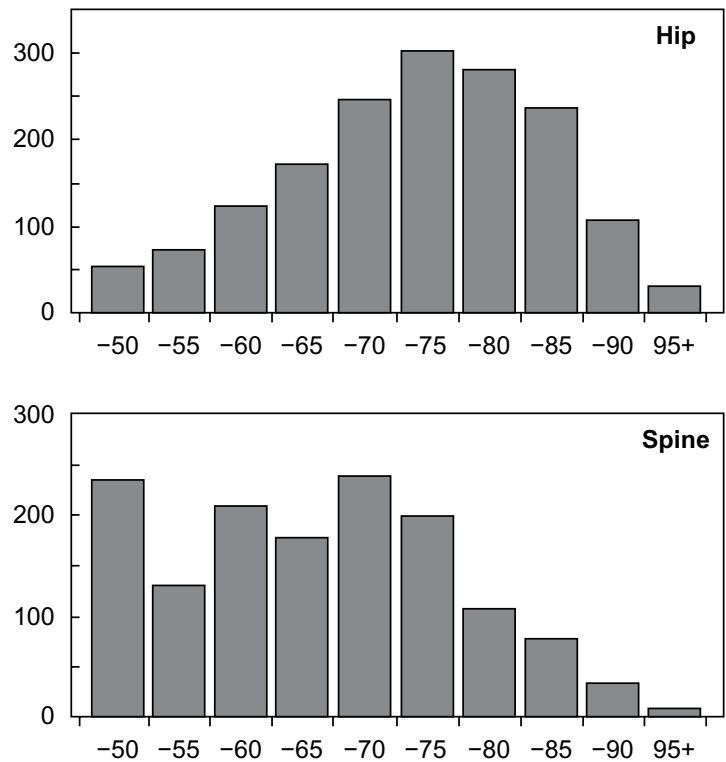
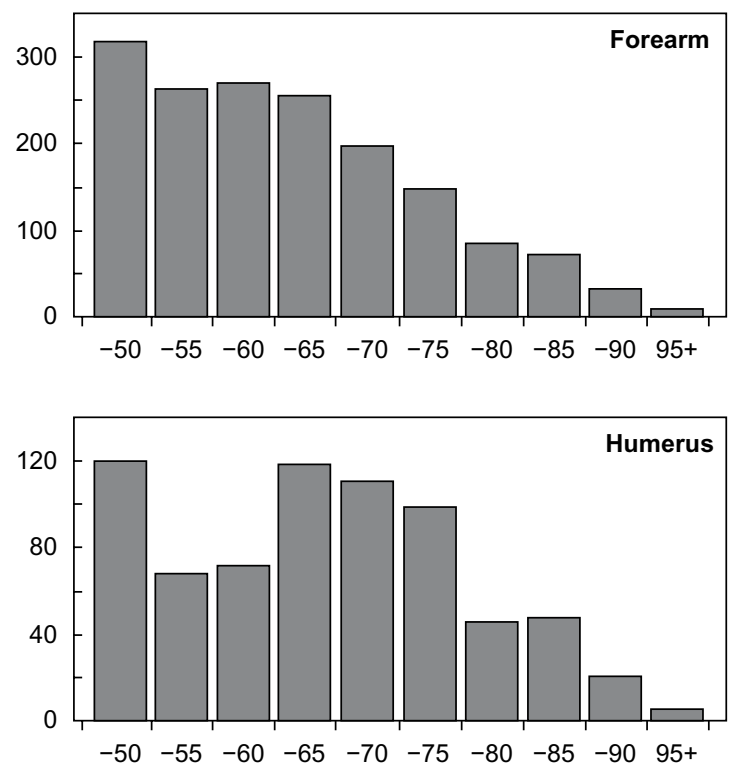

Age (years)

Figure I Number of common osteoporotic fractures by age worldwide in 2000.

Note: Reprinted from Springer and Osteoporos Int. 2006; I7(I2):I726-1733, Johnell O, Kanis JA. An estimate of the worldwide prevalence and disability associated with osteoporotic fractures. ${ }^{4}$ C 2006. With kind permission from Springer Science and Business Media.

less easily quantifiable indirect costs of pain, disability, and reduced quality of life that accompany fracture. ${ }^{46}$

Notwithstanding its high prevalence, osteoporosis is often underdiagnosed and undertreated. ${ }^{7-11}$ Moreover, even when the diagnosis is made and the decision is taken to treat, there are remaining challenges in implementing therapy for osteoporosis. Several patient populations are particularly challenging for clinicians to treat and are not as well studied as women with postmenopausal osteoporosis. These include men, the very elderly, disabled persons, patients with glucocorticoid-induced osteoporosis (GIOP) or renal impairment, patients after transplantation, high-risk patients who are not well-controlled despite therapy, and patients with preexisting gastrointestinal (GI) problems who cannot tolerate existing therapies. Indeed, the extent of under treatment tends to be greater for these patient populations than for postmenopausal women, ${ }^{12-16}$ perhaps, in part, because physicians are reluctant to initiate therapy owing to doubts about efficacy or concerns about side effects. The objective of this review was to describe existing challenges to improving the treatment of osteoporosis.

\section{General principles for diagnosing, preventing, and treating osteoporosis}

Osteoporosis is defined by the World Health Organization (WHO) as a systemic skeletal disease characterized by low bone mass and micro architectural deterioration of bone tissue, with a consequent increase in bone fragility and susceptibility to fracture. Several national and regional guidelines for diagnosing and managing osteoporosis have been published for the USA, Canada, and Europe, ${ }^{17-21}$ and a full list of guidelines worldwide is available on the International Osteoporosis Foundation website..$^{22}$ Lifestyle recommendations for reducing osteoporotic fracture risk include maintaining adequate calcium and vitamin $\mathrm{D}$ intake, regular weight-bearing and muscle-strengthening exercise, strategies to prevent falls, and avoiding tobacco and excessive alcohol consumption. Currently approved therapies to prevent or treat osteoporosis, summarized in Table 1, include the bisphosphonates (eg, alendronate, risedronate, ibandronate, and zoledronic acid), selective estrogen receptor modulators (SERMs) (eg, raloxifene), estrogen, calcitonin, parathyroid hormone (eg, teriparatide), the receptor activator of nuclear factor-kappa B ligand (RANKL) inhibitor, denosumab, and in some countries, strontium ranelate. ${ }^{17,23,24}$

The decision regarding when to initiate therapy to prevent osteoporotic fracture can be complex and must take into account the possible risk factors for the individual patient. The FRAX ${ }^{\circledR}$ tool has been developed by the WHO Collaborating Centre for Metabolic Bone Diseases to estimate the 10 -year probability of major osteoporotic and hip fracture, using an individual's clinical risk factors, with or without the hip bone mineral density (BMD) measurement (Table 2)..$^{25,26}$ There is great geographic heterogeneity in fracture risk, ${ }^{27}$ 
Table I Drugs approved for the prevention and treatment of osteoporosis

\begin{tabular}{|c|c|c|}
\hline Pharmacologic category & United States & European Union \\
\hline Bisphosphonate & $\begin{array}{l}\text { Alendronate } \\
\text { Risedronate } \\
\text { lbandronate } \\
\text { Zoledronic acid }\end{array}$ & $\begin{array}{l}\text { Alendronate } \\
\text { Risedronate } \\
\text { lbandronate } \\
\text { Zoledronic acid } \\
\text { Etidronate } \\
\text { Clodronate }^{\mathrm{b}}\end{array}$ \\
\hline $\begin{array}{l}\text { RANK ligand inhibitor } \\
\text { SERM }\end{array}$ & $\begin{array}{l}\text { Denosumab } \\
\text { Raloxifene }\end{array}$ & $\begin{array}{l}\text { Denosumab } \\
\text { Raloxifene } \\
\text { Bazedoxifene }^{\mathrm{a}}\end{array}$ \\
\hline $\begin{array}{l}\text { Parathyroid hormone } \\
\text { and derivatives }\end{array}$ & Teriparatide & $\begin{array}{l}\text { Teriparatide } \\
\text { Parathyroid hormone }\end{array}$ \\
\hline Other & $\begin{array}{l}\text { Estrogen/HRT } \\
\text { Calcitonin } \\
\text { Vitamin D }\end{array}$ & $\begin{array}{l}\text { HRT } \\
\text { Strontium ranelate } \\
\text { Calcitonin } \\
\text { Vitamin D and } \\
\text { derivatives }\end{array}$ \\
\hline
\end{tabular}

Notes: a Available only in Greece, Spain, and Germany; bapproved for osteoporosis in only some countries Data from Kanis et al, ${ }^{17}$ health.ny.gov, ${ }^{23}$ and nof.gov. ${ }^{24}$ Abbreviations: HRT, hormone replacement therapy; RANK, receptor activator of nuclear factor-kappa B; SERM, selective estrogen receptor modulator.

and the appropriate FRAX tool is chosen according to the country and as needed, ethnicity and the patient population. ${ }^{25}$ Further guidance for clinical decision-making when using FRAX has been published. ${ }^{28}$

\section{Patient populations posing particular challenges for physicians Patients with glucocorticoid- induced osteoporosis}

The development of osteoporosis is a serious concern for patients who require long-term glucocorticoid therapy, such as for inflammatory joint disease or asthma. Glucocorticoids exert both direct and indirect effects on bone that contribute to increased fracture risk (Figure 2). ${ }^{29} \mathrm{~A}$ decline in BMD begins within the first 3 months of glucocorticoid therapy; the rate of decline is most rapid during the first 6-12 months and slows

Table 2 Risk factors included in the WHO fracture risk assessment model $\left(\right.$ FRAX $\left.{ }^{\circledR}\right)$

- Current age

- Sex

- A prior osteoporotic fracture (including morphometric vertebral fracture)

- Femoral neck BMD

- Low body mass index $\left(\mathrm{kg} / \mathrm{m}^{2}\right)$

- Rheumatoid arthritis

- Secondary osteoporosis

- Parental history of hip fracture

- Current smoking

- Alcohol intake (3 or more drinks/day)

- Oral glucocorticoids $\geq 5 \mathrm{mg} /$ day of prednisone for $\geq 3$ months (forever)

Note: Fracture risk assessment model $\left(\right.$ FRAX $\left.^{\circledR}\right) .^{27}$

Abbreviations: BMD, bone mineral density; WHO, World Health Organization. thereafter. ${ }^{30}$ However, the risk of fracture increases faster than can be explained by the loss of BMD alone; this is thought to be the result of disrupted architecture of the bone, particularly cancellous bone, and possibly other factors, including the rapidity of bone loss, myopathy, increased tendency to fall, and the condition for which the glucocorticoids were prescribed. ${ }^{29,31}$ As many as $30 \%-50 \%$ of patients receiving long-term glucocorticoid therapy experience a fracture, often at higher BMD levels than in postmenopausal women, with fragility fracture and, most commonly, of the vertebrae or proximal femur. ${ }^{29}$

Recommendations for preventing and treating GIOP have been published; ${ }^{31-33}$ however, several areas of uncertainty remain, including the threshold glucocorticoid dose for initiating preventive therapy. The risk of GIOP has not been defined for lower doses of glucocorticoids $(<5-7.5 \mathrm{mg}$ /day prednisone) nor for intermittent rather than continuous administration. Moreover, with regard to treatment efficacy, the majority of clinical trials examine changes in BMD; few examine fracture endpoints for patients with GIOP. ${ }^{34}$ Finally, patients with GIOP are at increased risk of fracture but are already receiving drugs (steroids) that can cause GI upset, adding to the difficulty of prescribing concomitant osteoporosis therapy. ${ }^{35}$

\section{Patients with renal impairment}

Patients with renal impairment are also at increased risk of fracture. For women 65 years and older, hip fracture risk increases as estimated glomerular filtration rate (eGFR) decreases below $60 \mathrm{~mL} / \mathrm{min},{ }^{36}$ while for both men and women, the hip fracture risk with an eGFR of $<60 \mathrm{~mL} / \mathrm{min}$ is double that with eGFR $\geq 60 \mathrm{~mL} / \mathrm{min} .{ }^{37}$ As many as half of patients with renal impairment have experienced a fracture by the time they initiate dialysis, ${ }^{38}$ and for patients on dialysis, the mortality rate during the year after hip fracture is 2.5 times higher than that in the general population. ${ }^{39}$

The etiology of fracture in patients with renal impairment is complex as renal impairment itself is characterized by abnormalities of bone and mineral metabolism, as well as an increased tendency to fall because of muscle weakness and impaired balance. ${ }^{38}$ In the early stages of renal impairment (stages $1-3$; GFR $\geq 30 \mathrm{~mL} / \mathrm{min} / 1.73 \mathrm{~m}^{2}$ ), the association of lower BMD and higher fracture risk is present. ${ }^{38}$ However, in patients with stage 4 (GFR $15-29 \mathrm{~mL} / \mathrm{min} / 1.73 \mathrm{~m}^{2}$ ) and stage 5 (GFR $<15 \mathrm{~mL} / \mathrm{min} / 1.73 \mathrm{~m}^{2}$ or on dialysis), evidence is lacking for the associations among bone quality, bone turnover markers, neuromuscular function, and fractures; and $\mathrm{BMD}$ may no longer be reliable in predicting fracture 


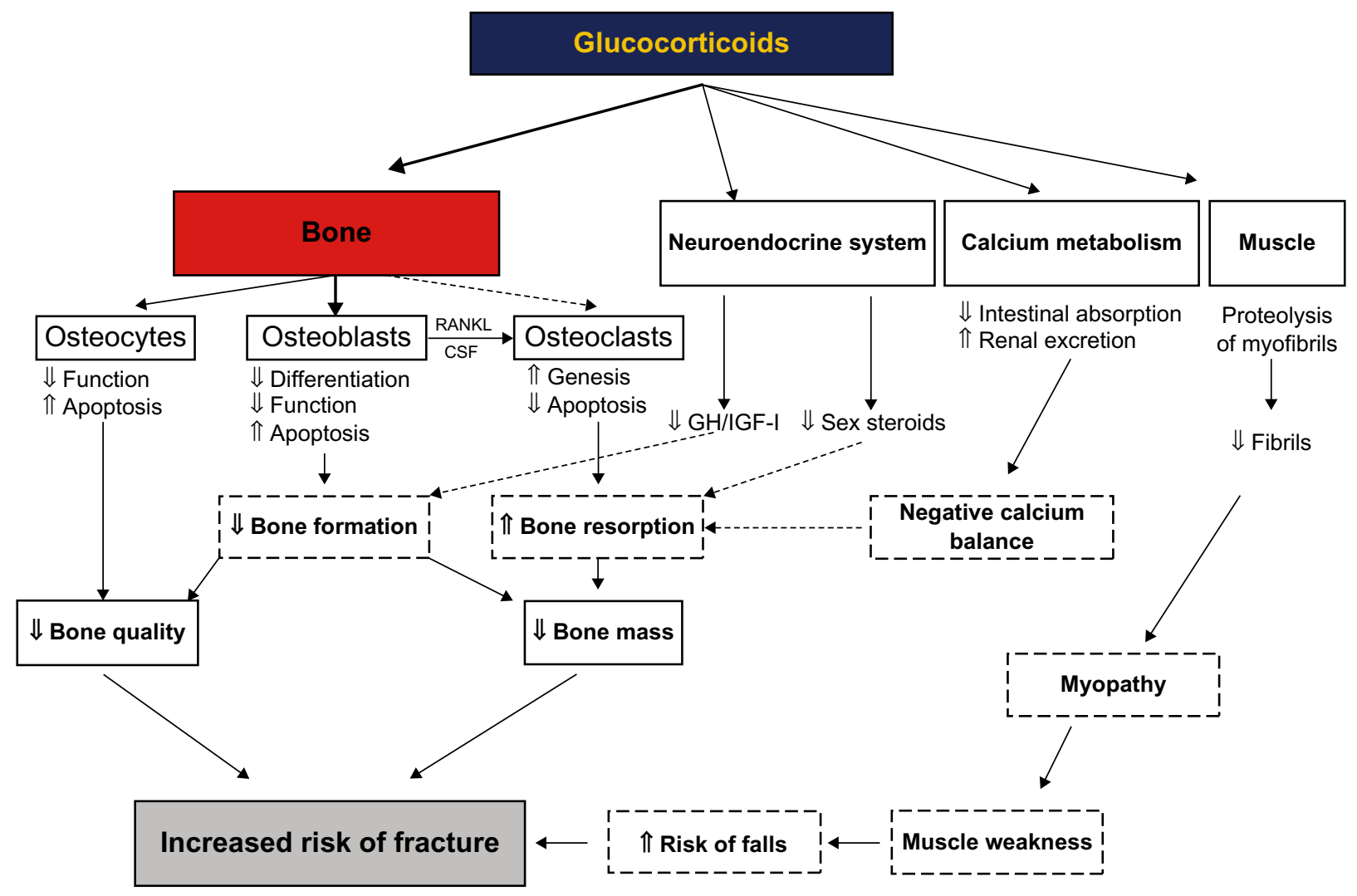

Figure 2 Diagram showing the direct and indirect effects of glucocorticoids on bone, leading to glucocorticoid-induced osteoporosis and fractures.

Notes: Reprinted from Springer and Osteoporos Int, 18; 2007, I3 19-1328, Glucocorticoid-induced osteoporosis: pathophysiology and therapy, Canalis E, Mazziotti G, Giustina A, Bilezikian JP, Figure I. ${ }^{29}$ @) 2007. With kind permission from Springer Science and Business Media.

Abbreviations: CSF, cerebrospinal fluid; GH, growth hormone; IGF, insulin-like growth factor; RANKL, receptor activator of nuclear factor-kappa B ligand.

risk. For these patients, it becomes increasingly difficult to differentiate between osteoporosis and chronic kidney disease-mineral and bone disorder (CKD-MBD) (defined in Table 3), ${ }^{40,41}$ conditions for which the treatment differs. ${ }^{38}$

Physicians therefore face several challenges in treating patients with renal impairment and low BMD or fracture. Patients with renal impairment are often on multiple medications and may not tolerate additional therapy. Moreover, the bisphosphonates are excreted through the kidneys, a matter of concern if renal function is impaired. ${ }^{42}$ The US Food and Drug Administration (FDA) and product manufacturers have defined a creatinine clearance (which runs slightly higher

Table 3 Definition of chronic kidney disease-mineral and bone disorder, according to KDIGO

A systemic disorder of mineral and bone metabolism due to CKD and manifested by one or a combination of the following

I. Abnormalities of calcium, phosphorus, PTH, or vitamin D metabolism

2. Abnormalities in bone turnover, mineralization, volume, linear growth, or strength

3. Vascular or other soft tissue calcification

Note: Data from Moe et a $\left.\right|^{41}$ and Miller. ${ }^{42}$

Abbreviations: CKD, chronic kidney disease; KDIGO, Kidney Disease: Improving Global Outcomes; PTH, parathyroid hormone. than GFR) of $35 \mathrm{~mL} / \mathrm{min}$ as the threshold below which therapy with alendronate and zoledronic acid is not recommended; for ibandronate and risedronate, the threshold is $30 \mathrm{~mL} / \mathrm{min} \cdot{ }^{43-46}$ Nonetheless, while bisphosphonate therapy is approved for use in patients with stages 1-3 renal impairment, the cutoff point for initiating therapy is not defined for those patients who have not yet experienced fragility fracture. Moreover, for patients with GFR $<30-35 \mathrm{~mL} / \mathrm{min}$, distinguishing between osteoporosis and CKD-MBD can be difficult. ${ }^{42}$

Jamal et $\mathrm{al}^{38}$ summarized the existing knowledge for determining fracture risk for patients with renal impairment. Published guidelines provide recommendations for working with these patients; however, the guidelines are admittedly weak or discretionary because of the lack of trials reporting clinical outcomes (fractures). ${ }^{38,40,47}$ For patients with osteoporosis or at high risk of fracture who are at stages 1 and 2 or stage 3 with normal parathyroid hormone, the consensus guidelines recommend treatment as for the general population. Little evidence is available for the treatment of patients with stage 3 renal impairment with biochemical abnormalities and stages $4-5,{ }^{40,47}$ 
although Miller $^{48}$ has published a practical opinion-based approach for these patients.

\section{Men}

Osteoporosis is often considered a "woman's disease;" however, worldwide, $39 \%$ of osteoporotic fractures occur in men, ${ }^{4}$ and in the USA, the projections for 2005 attributed $29 \%$ of the fractures and $25 \%$ of the costs of osteoporosis to men. ${ }^{2}$ Nonetheless, the preponderance of clinical trials has studied postmenopausal women, with men constituting a small proportion of enrolled patients. Most importantly, few trials have examined fracture endpoints for men $^{49-52}$; thus, physicians have little basis for assuring their male patients of treatment efficacy.

Age-related bone loss develops more slowly and at older ages in men. The key risk factors for osteoporotic fracture in men identified in a recent meta-analysis ${ }^{53}$ include increased age, low body weight, weight loss, physical inactivity, prolonged corticosteroid use, previous osteoporotic fracture, and androgen-deprivation therapy. The three most common causes of secondary osteoporosis in men are 1) glucocorticoid excess, usually secondary to chronic glucocorticoid therapy; 2) alcohol abuse; and 3) hypogonadism, increasingly common with the use of androgen-deprivation therapy for prostate cancer. ${ }^{50,54}$ While there are sex-specific differences in osteoporosis pathophysiology, ${ }^{50,51}$ the prevention and treatment of osteoporosis in men are as important as for women at risk of first or subsequent fracture. After a first fragility fracture, men, similar to women, are at higher risk of subsequent fracture, ${ }^{55,56}$ and the increased mortality risk after fracture in men persists for 5-10 years and is similar to or higher, in some studies, than that for women..$^{56-58}$

The number of osteoporosis therapies approved for men are fewer than for women, and not many clinical trials examine fracture endpoints for men; however, in trials using surrogate markers for fracture, such as BMD and markers of bone turnover, the effects of osteoporosis therapies have been similar for men and women, suggesting that treatment efficacy for preventing fracture is similar for the two sexes. ${ }^{49-52}$ The current guidance thus recommends that men receive similar treatment to that for women with osteoporosis. ${ }^{50} \mathrm{The}$ importance of determining osteoporotic fracture risk, effective prevention, and optimal therapy specifically for men is increasingly recognized, ${ }^{50}$ and recent studies have indeed focused on men. ${ }^{59-61}$

An important component of the treatment for male patients with osteoporosis is countering the common perception that osteoporosis is a concern only for women. ${ }^{62} \mathrm{As}$ reported by Solimeo et al, ${ }^{62}$ men rarely consider osteoporosis to be a possible cause of their back pain or a result of aging or cancer treatment. The men they interviewed reported surprise at learning of the osteoporosis diagnosis; many believed that osteoporosis therapies have been insufficiently studied in men, were reluctant to take medications, and felt dissatisfied with side effects of therapy.

\section{The very elderly}

Advanced age is an important risk factor for osteoporosis and fracture for both men and women. ${ }^{50,63-65}$ The prevalence of osteoporosis and risk of associated fracture increase with age, which is the criterion listed first in all geographic versions of the FRAX tool to estimate the 10-year probability of hip or other major osteoporotic fracture. ${ }^{25}$ With advancing age, the balance between bone formation and bone resorption is altered, favoring resorption and thus, bone loss. The resultant bone fragility is coupled with an increased risk of falls among the elderly because of reduced muscle strength, poor balance, comorbidities, such as osteoarthritis, side effects of medications, or a combination of these. ${ }^{64-66}$ The prevention of osteoporotic fracture for the very elderly thus requires dual strategies to prevent falls as well as to increase BMD.

The challenges are many in choosing and particularly, in maintaining pharmacological therapy for osteoporosis in very elderly patients. Patients over 80 years of age are not well-represented in clinical trials, and thus, this population has been insufficiently studied. ${ }^{64}$ Moreover, many of these patients have comorbidities and are on multiple medications. ${ }^{67}$ Polypharmacy increases the possibility of side effects and of falling and can reduce adherence to medications. An absence of perceived benefit, the occurrence of side effects, and the inability to comply with stringent administration protocols because of physical or mental disability are reported factors that can contribute to the potential for nonadherence. ${ }^{17,67-69}$ Other common barriers to optimal adherence by elderly patients include dementia, Parkinson's disease, and lack of social support. ${ }^{67,70,71}$ Moreover, GI intolerance to therapies, discussed further below, may be especially problematic for the very elderly. ${ }^{72}$

\section{High-risk patients who are not well-controlled despite being on osteoporosis therapy}

Therapy for osteoporosis reduces but does not eliminate the risk of fracture. ${ }^{52,73}$ High-risk patients who are not wellcontrolled can be defined as those patients who experience fractures or decline in $\mathrm{BMD}$, or whose BMD remains in 
osteoporotic range, while receiving osteoporosis therapy. The risk factors identified for postmenopausal women who show inadequate response to therapy include a prior fragility fracture and low levels of 25-hydroxy vitamin D $(<20 \mathrm{ng} / \mathrm{mL}) .{ }^{74,75}$ A significant reduction in quality of life has been reported for these women. ${ }^{75,76}$ Knowledge of the risk factors and an understanding of inadequate response are important for clinicians to identify patients who require close monitoring during treatment and to determine when a change in therapy is warranted. The identification of these patients will vary on a case-by-case basis according to physician opinion and individual patient circumstances.

The International Osteoporosis Foundation (IOF) has established a working group to study what constitutes an inadequate response to therapy. ${ }^{77}$ The current IOF operational definition of "failure of treatment" is the occurrence of two or more incident fractures during treatment, a continuing decrease in BMD, and no suppression of bone remodeling markers by antiresorptive therapy. ${ }^{78}$ These criteria assume that the patient has 1) good adherence to therapy, 2) adequate calcium and vitamin D supplementation, and 3) a treatment period of at least 1 year.

\section{Issues that can affect patient adherence to therapy for osteoporosis}

Suboptimal adherence to prescribed medication is a common and well-recognized problem with regard to long-term therapy for chronic diseases, ${ }^{79,80}$ and adherence to treatment for osteoporosis is no exception. ${ }^{81-87}$ The lack of adherence to osteoporosis therapy results in increased risk of fracture, higher medical costs, and increases in hospitalizations. ${ }^{82,84,88-90}$ Conversely, better adherence to osteoporosis therapies is associated with greater reduction in fracture risk; ${ }^{91-93}$ and a recent study reports reduced mortality risk in women and possibly men receiving osteoporosis therapy. ${ }^{94}$

Adherence, synonymous with compliance, is defined as the proportion of doses taken as prescribed, while persistence is used to describe the length of time for which the regimen is followed. Poor adherence and persistence can result from forgetfulness, inability to pay, or other nonintentional reasons. The degree of intentional adherence has been associated with the balance between patients' beliefs about the necessity of their medications and their concerns about medication side effects and safety. ${ }^{95,96}$ For patients with osteoporosis, the failure to perceive their increased risk of fracture ${ }^{97,98}$ or lack of satisfaction with treatment ${ }^{99}$ has been associated with poor adherence. Fear of side effects, including GI side effects, is another important cause of suboptimal adherence or poor persistence with therapy. ${ }^{68,69,100,101}$ Patients often have concerns even before initiating therapy as they may have heard about the side effects of osteoporosis therapy; therefore, the possible occurrence of side effects, whether real or perceived, is a problem.

A recent study has found that some physicians may not prescribe treatment for osteoporosis because of concerns about adverse effects. ${ }^{102}$ Tolerability concerns are relevant for physicians, especially with regard to the patient populations described above, as well as for patients with preexisting GI problems. For example, patients with gastroesophageal reflux disease often do not tolerate the addition of oral bisphosphonate therapy. Indeed, GI intolerance has been a large enough barrier to treatment that less frequent dosing regimens and intravenous (IV) delivery routes have been developed. ${ }^{103}$ Weekly regimens have indeed improved adherence and persistence levels over daily regimens; ${ }^{104-106}$ nonetheless, these advances have not been enough to result in optimal adherence. ${ }^{107,108}$ Moreover, while IV therapies have bypassed the problem of GI intolerance, persistence with IV regimens is also suboptimal, often because of adverse effects (postinfusion syndrome). ${ }^{109,110}$ It has been previously reported that persistence with IV zoledronate is comparable with that of oral bisphosphonates after a year. Studies have shown that men are more likely to discontinue IV therapies; in addition, adverse effects, most commonly postinfusion syndrome, and a poor understanding of the benefits and risks of IV zoledronate are risk factors for discontinuation.

Bisphosphonates have been found to be generally welltolerated in randomized controlled trials, with upper GI events and discontinuation rates similar to those of placebo. ${ }^{11,112}$ However, patients with preexisting active GI conditions are usually excluded from these trials. A large prospective, observational US study found that GI side effects among women receiving osteoporosis therapy were common, with odds 1.5 times higher for women receiving bisphosphonates than other therapies; and GI side effects were associated with increased therapy discontinuation. ${ }^{113}$ Moreover, data from real-world clinical practice suggest that GI side effects are an issue for patients, possibly because of improper drug administration. ${ }^{114}$ Elderly patients in particular, may have difficulty complying with the requirement to take oral bisphosphonates early in the morning, with a full glass of water, while remaining upright and fasting for at least 30 minutes. Patients who experience GI side effects with bisphosphonates often have an underlying comorbidity or concomitant treatment, such as nonsteroidal anti-inflammatory drugs 
or glucocorticoids, that would predispose them to these side effects. ${ }^{35}$ These treatments themselves may cause GI side effects, leading to uncertainty around the drug that caused them. In addition, evidence suggests that GI problems are greater with generic bisphosphonates. ${ }^{115,116}$

\section{Discussion}

Substantial progress has been made over the past two decades in improving our understanding of osteoporosis and fracture risk in different patient populations. However, many therapeutic challenges remain. The challenges from the physician's perspective include the lack of information on how to treat specific patient populations and once treatment is initiated, how to allay patient concerns about side effects and how to encourage patient adherence to therapy. The challenges from the patient's perspective include reaching an understanding of the condition and maintaining adherence to chronic therapy, despite concerns about or the actual occurrence of side effects. Further study is needed to quantify and better characterize the specific patient populations at risk of osteoporotic fracture, including men, the very elderly, patients with GIOP and renal impairment, high-risk patients not well-controlled despite therapy, and patients who experience GI side effects.

Simple steps that can be taken for all patients at risk of fracture include instituting the measures recommended by the American College of Rheumatology for preventing and treating GIOP, namely, promoting general health awareness, ensuring that patients receive sufficient calcium and vitamin $\mathrm{D}$, and for patients receiving glucocorticoids, reducing the glucocorticoid dose to a minimum. ${ }^{31}$ The tendency to fall is an important fracture risk factor for the very elderly; thus, vitamin D supplementation and appropriate exercises are key components of osteoporosis therapy and fracture prevention. ${ }^{64,65}$

These measures are indicated for patients after fracture as well; however, the under diagnosis and under treatment of osteoporotic fracture, particularly among men, remain all too common. ${ }^{9-11}$ Thus, the evaluation of all older patients with fracture is essential to close the postfracture care gap. In one study, an intervention program instituted by clinical pharmacy specialists to identify patients with atraumatic fracture was successful in improving osteoporosis treatment initiation rates among elderly patients, by ensuring they were screened for osteoporosis and then treated appropriately. ${ }^{117}$

Once the decision to institute therapy is made, patient education about osteoporosis and fracture risk should be provided. This is particularly important for men, who may not be aware that osteoporosis can be a concern. Patients' beliefs about fracture risk and need for therapy are influenced by the perceived attitudes and support of physicians and other health care providers. ${ }^{69,118}$ Secondary prevention programs, including fracture liaison services, bone-therapy groups, telephone calls from a nurse or other health care provider, and scheduling regular follow-up visits, have been shown to improve patient adherence and persistence with therapy. ${ }^{119,120}$ Newman et al reported success in improving adherence and BMD with a targeted program enrolling patients on chronic glucocorticoid therapy. ${ }^{121}$

Postmenopausal women constitute the largest population in need of effective strategies to promote adherence and persistence with osteoporosis therapy. With regard to postmenopausal osteoporosis, the results of economic modeling suggest that nonadherence and nonpersistence are costly and that behavioral interventions to improve adherence and persistence with therapy would be cost effective. ${ }^{122,123}$ It is possible that these results could apply also to other patient groups with osteoporosis as well.

\section{Conclusion}

In conclusion, several patient populations are particularly challenging for clinicians to treat and require further study with regard to osteoporosis therapy. Clearly, more data are needed to guide the treatment of men, the very elderly, patients with GIOP and renal impairment, high-risk patients not well-controlled despite therapy, and patients who experience GI side effects. Therapies are needed that are viewed as effective and safe by both physicians and patients, and as convenient to take by patients.

\section{Acknowledgments}

Editorial assistance was provided by Elizabeth V Hillyer, DVM. This assistance was funded by Merck Sharp and Dohme Corp, a subsidiary of Merck and Co, Inc, Whitehouse Station, NJ.

\section{Disclosure}

AM and SS are employees of Merck, the study sponsor. The authors report no other conflicts of interest in this work.

\section{References}

1. Dawson-Hughes B, Looker AC, Tosteson AN, Johansson H, Kanis JA, Melton LJ. The potential impact of the National Osteoporosis Foundation guidance on treatment eligibility in the USA: an update in NHANES 2005-2008. Osteoporos Int. 2012;23(3):811-820.

2. Burge R, Dawson-Hughes B, Solomon DH, Wong JB, King A, Tosteson A. Incidence and economic burden of osteoporosis-related fractures in the United States, 2005-2025. J Bone Miner Res. 2007;22(3):465-475. 
3. Cooper C, Cole ZA, Holroyd CR, et al; IOF CSA Working Group on Fracture Epidemiology. Secular trends in the incidence of hip and other osteoporotic fractures. Osteoporos Int. 2011;22(5):1277-1288.

4. Johnell O, Kanis JA. An estimate of the worldwide prevalence and disability associated with osteoporotic fractures. Osteoporos Int. 2006; 17(12):1726-1733.

5. Kanis JA, Johnell O. Requirements for DXA for the management of osteoporosis in Europe. Osteoporos Int. 2005;16(3):229-238.

6. Adachi JD, Adami S, Gehlbach S, et al; GLOW Investigators. Impact of prevalent fractures on quality of life: baseline results from the global longitudinal study of osteoporosis in women. Mayo Clin Proc. 2010;85(9):806-813.

7. Sale JE, Beaton D, Posen J, Elliot-Gibson V, Bogoch E. Systematic review on interventions to improve osteoporosis investigation and treatment in fragility fracture patients. Osteoporos Int. 2011;22(7):2067-2082.

8. Shepherd AJ, Cass AR, Ray LA, Tan A, Wilkinson GS. Treatment for older men with fractures. Osteoporos Int. 2012;23(3):1041-1051.

9. Delmas PD, van de Langerijt L, Watts NB, et al; IMPACT Study Group. Underdiagnosis of vertebral fractures is a worldwide problem: the IMPACT study. J Bone Miner Res. 2005;20(4):557-563.

10. Shibli-Rahhal A, Vaughan-Sarrazin MS, Richardson K, Cram P. Testing and treatment for osteoporosis following hip fracture in an integrated US. healthcare delivery system. Osteoporos Int. 2011;22(12):2973-2980.

11. Leslie WD, Giangregorio LM, Yogendran M, et al. A population-based analysis of the post-fracture care gap 1996-2008: the situation is not improving. Osteoporos Int. 2012;23(5):1623-1629.

12. Feldstein AC, Nichols GA, Elmer PJ, Smith DH, Aickin M, Herson M. Older women with fractures: patients falling through the cracks of guideline-recommended osteoporosis screening and treatment. $J$ Bone Joint Surg Am. 2003;85-A(12):2294-2302.

13. Johnell K, Fastbom J. Undertreatment of osteoporosis in the oldest old? A nationwide study of over 700,000 older people. Arch Osteoporos. 2009;4(1-2):17-23.

14. Kiebzak GM, Beinart GA, Perser K, Ambrose CG, Siff SJ, Heggeness MH. Undertreatment of osteoporosis in men with hip fracture. Arch Intern Med. 2002;162(19):2217-2222.

15. Majumdar SR, Lix LM, Yogendran M, Morin SN, Metge CJ, Leslie WD. Population-based trends in osteoporosis management after new initiations of long-term systemic glucocorticoids (1998-2008). J Clin Endocrinol Metab. 2012;97(4):1236-1242.

16. McKeown E, Bykerk VP, De Leon F, et al; CATCH Investigators. Quality assurance study of the use of preventative therapies in glucocorticoidinduced osteoporosis in early inflammatory arthritis: results from the CATCH cohort. Rheumatology (Oxford). 2012;51(9): 1662-1669.

17. Kanis JA, McCloskey EV, Johansson H, Cooper C, Rizzoli R, Reginster JY; Scientific Advisory Board of the European Society for Clinical and Economic Aspects of Osteoporosis and Osteoarthritis (ESCEO) and the Committee of Scientific Advisors of the International Osteoporosis Foundation (IOF). European guidance for the diagnosis and management of osteoporosis in postmenopausal women. Osteoporos Int. 2013;24(1):23-57.

18. National Osteoporosis Foundation. 2013 Clinician's Guide to the Prevention and Treatment of Osteoporosis. Washington, DC: National Osteoporosis Foundation; 2013. Available from: http://nof.org/hcp/ resources/913. Accessed May 24, 2013.

19. nice.org.uk [homepage on the Internet]. Alendronate, etidronate, risedronate, raloxifene, strontium ranelate and teriparatide for the secondary prevention of osteoporotic fragility fractures in postmenopausal women [NICE technology appraisal guidance TA161]. NHS National Institute for Health and Clinical Excellence (NICE); 2011 [updated August 27, 2013; cited May 24, 2013]. Available from: http://guidance.nice.org. uk/TA161. Accessed October 24, 2013.

20. NHS National Institute for Health and Clinical Excellence (NICE). Alendronate, Etidronate, Risedronate, Raloxifene and Strontium Ranelate for the Primary Prevention of Osteoporotic Fragility Fractures in Postmenopausal Women (Amended). NICE Technology Appraisal Guidance 160 (Amended). London: National Institute for Health and Clinical Excellence; 2011. Available from: http://www.nice.org.uk/ nicemedia/live/11746/47176/47176.pdf. Accessed May 24, 2013.
21. Papaioannou A, Morin S, Cheung AM, et al; Scientific Advisory Council of Osteoporosis Canada. 2010 clinical practice guidelines for the diagnosis and management of osteoporosis in Canada: summary. CMAJ. 2010;182(17):1864-1873.

22. iofbonehealth.org [homepage on the Internet]. National and regional osteoporosis guidelines. International Osteoporosis Foundation; 2013 [cited May 24, 2013]. Available from: http://www.iofbonehealth.org/ national-regional-osteoporosis-guidelines. Accessed October 24, 2013.

23. health.ny.gov [homepage on the Internet]. FDA-approved medications for osteoporosis treatment. New York State Osteoporosis Prevention and Education Program; 2012 [updated Jun 2012, cited May 24, 2013]. Available from: http://www.health.ny.gov/diseases/conditions/osteoporosis/ fda_meds_and_prevention.htm. Accessed October 24, 2013.

24. nof.gov [homepage on the Internet]. Types of osteoporosis medications. National Osteoporosis Foundation; 2013 [cited May 24, 2013]. Available from: http://www.nof.org/articles/22. Accessed October 24, 2013.

25. shef.ac.uk [homepage on the Internet]. FRAX ${ }^{\circledR}$ WHO Fracture Risk Assessment Tool. World Health Organization Collaborating Centre for Metabolic Bone Diseases, University of Sheffield; 2013 [cited May 24, 2013]. Available from: http://www.shef.ac.uk/FRAX/. Accessed October 24, 2013

26. Kanis JA; World Health Organization Scientific Group. Assessment of Osteoporosis at the Primary Health Care Level. Technical Report. Sheffield: World Health Organization Collaborating Centre for Metabolic Bone Diseases, University of Sheffield; 2007.

27. Kanis JA, Odén A, McCloskey EV, Johansson H, Wahl DA, Cooper C; IOF Working Group on Epidemiology and Quality of Life. A systematic review of hip fracture incidence and probability of fracture worldwide. Osteoporos Int. 2012;23(9):2239-2256.

28. Lewiecki EM, Compston JE, Miller PD, et al; FRAX ${ }^{\circledR}$ Position Development Conference Members. Official positions for FRAX ${ }^{\circledR}$ bone mineral density and FRAX ${ }^{\circledR}$ simplification from Joint Official Positions Development Conference of the International Society for Clinical Densitometry and International Osteoporosis Foundation on FRAX ${ }^{\circledR}$. J Clin Densitom. 2011;14(3):226-236.

29. Canalis E, Mazziotti G, Giustina A, Bilezikian JP. Glucocorticoidinduced osteoporosis: pathophysiology and therapy. Osteoporos Int. 2007;18(10):1319-1328.

30. Weinstein RS. Clinical practice. Glucocorticoid-induced bone disease. N Engl J Med. 2011;365(1):62-70.

31. Grossman JM, Gordon R, Ranganath VK, et al. American College of Rheumatology 2010 recommendations for the prevention and treatment of glucocorticoid-induced osteoporosis. Arthritis Care Res (Hoboken). 2010;62(11):1515-1526.

32. Bone and Tooth Society, National Osteoporosis Society, Royal College of Physicians. Glucocorticoid-induced osteoporosis: guidelines for prevention and treatment. London: London: Royal College of Physicians; 2002.

33. Devogelaer JP, Goemaere S, Boonen S, et al. Evidence-based guidelines for the prevention and treatment of glucocorticoid-induced osteoporosis: a consensus document of the Belgian Bone Club. Osteoporos Int. 2006;17(1):8-19.

34. Adachi JD, Saag KG, Delmas PD, et al. Two-year effects of alendronate on bone mineral density and vertebral fracture in patients receiving glucocorticoids: a randomized, double-blind, placebocontrolled extension trial. Arthritis Rheum. 2001;44(1):202-211.

35. Vestergaard P, Schwartz K, Pinholt EM, Rejnmark L, Mosekilde L. Gastric and esophagus events before and during treatment of osteoporosis. Calcif Tissue Int. 2010;86(2):110-115.

36. Ensrud KE, Lui LY, Taylor BC, et al; Osteoporotic Fractures Research Group. Renal function and risk of hip and vertebral fractures in older women. Arch Intern Med. 2007;167(2):133-139.

37. Nickolas TL, McMahon DJ, Shane E. Relationship between moderate to severe kidney disease and hip fracture in the United States. J Am Soc Nephrol. 2006;17(11):3223-3232.

38. Jamal SA, West SL, Miller PD. Fracture risk assessment in patients with chronic kidney disease. Osteoporos Int. 2012;23(4):1191-1198. 
39. Coco M, Rush H. Increased incidence of hip fractures in dialysis patients with low serum parathyroid hormone. Am J Kidney Dis. 2000;36(6):1115-1121.

40. Kidney disease: Improving Global Outcomes (KDIGO) CKD-MBD Work Group. KDIGO clinical practice guideline for the diagnosis, evaluation, prevention, and treatment of Chronic Kidney DiseaseMineral and Bone Disorder (CKD-MBD). Kidney Int Suppl. 2009;(113): S1-S130.

41. Moe S, Drüeke T, Cunningham J, et al; Kidney Disease: Improving Global Outcomes (KDIGO). Definition, evaluation, and classification of renal osteodystrophy: a position statement from Kidney Disease: Improving Global Outcomes (KDIGO). Kidney Int. 2006;69(11) 1945-1953.

42. Miller PD. The kidney and bisphosphonates. Bone. 2011;49(1):77-81.

43. fda.gov [homepage on the Internet]. FDA drug safety communication: New contraindication and updated warning on kidney impairment for Reclast (zoledronic acid). US Food and Drug Administration (FDA); 2011 [updated September 20, 2011, cited October 10, 2013]. Available from: http://www.fda.gov/Drugs/DrugSafety/ucm270199. htm. Accessed October 10, 2013.

44. Fosamax ${ }^{\circledR}$ (alendronate sodium) [package insert]. Whitehouse Station, NJ: Merck and Co, Inc; 2012.

45. Actonel ${ }^{\mathbb{}}$ (risedronate sodium) [package insert]. Norwich Pharmaceuticals, Inc., North Norwich, NY. 2012

46. Boniva ${ }^{\circledR}$ (ibandronate sodium) [package insert]. San Francisco, CA: Genentech, Inc; 2011.

47. Uhlig K, Berns JS, Kestenbaum B, et al. KDOQI US commentary on the 2009 KDIGO Clinical Practice Guideline for the Diagnosis, Evaluation, and Treatment of CKD-Mineral and Bone Disorder (CKD-MBD). Am J Kidney Dis. 2010;55(5):773-799.

48. Miller PD. Fragility fractures in chronic kidney disease: an opinionbased approach. Cleve Clin J Med. 2009;76(12):715-723.

49. Donaldson MG, Cawthon PM, Lui LY, et al; Osteoporotic Fractures in Men (MrOS) Study Group. Estimates of the proportion of older white men who would be recommended for pharmacologic treatment by the new US National Osteoporosis Foundation guidelines. J Bone Miner Res. 2010;25(7):1506-1511.

50. Kanis JA, Bianchi G, Bilezikian JP, et al. Towards a diagnostic and therapeutic consensus in male osteoporosis. Osteoporos Int. 2011;22(11): 2789-2798.

51. Gates BJ, Das S. Management of osteoporosis in elderly men. Maturitas. 2011;69(2):113-119.

52. MacLean C, Newberry S, Maglione M, et al. Systematic review: comparative effectiveness of treatments to prevent fractures in men and women with low bone density or osteoporosis. Ann Intern Med. 2008;148(3):197-213.

53. Liu H, Paige NM, Goldzweig CL, et al. Screening for osteoporosis in men: a systematic review for an American College of Physicians guideline. Ann Intern Med. 2008;148(9):685-701.

54. Ebeling PR. Clinical practice. Osteoporosis in men. $N$ Engl J Med. 2008;358(14):1474-1482.

55. Center JR, Bliuc D, Nguyen TV, Eisman JA. Risk of subsequent fracture after low-trauma fracture in men and women. JAMA. 2007;297(4): 387-394.

56. Bliuc D, Nguyen ND, Milch VE, Nguyen TV, Eisman JA, Center JR. Mortality risk associated with low-trauma osteoporotic fracture and subsequent fracture in men and women. JAMA. 2009;301(5):513-521.

57. Kannegaard PN, van der Mark S, Eiken P, Abrahamsen B. Excess mortality in men compared with women following a hip fracture. National analysis of comedications, comorbidity and survival. Age Ageing. 2010;39(2):203-209.

58. Wehren LE, Hawkes WG, Orwig DL, Hebel JR, Zimmerman SI, Magaziner J. Gender differences in mortality after hip fracture: the role of infection. J Bone Miner Res. 2003;18(12):2231-2237.

59. Cawthon PM, Ewing SK, McCulloch CE, et al; Osteoporotic Fractures in Men (MrOS) Research Group. Loss of hip BMD in older men: the osteoporotic fractures in men (MrOS) study. $J$ Bone Miner Res. 2009;24(10):1728-1735
60. Ensrud KE, Taylor BC, Paudel ML, et al; Osteoporotic Fractures in Men Study Group. Serum 25-hydroxyvitamin D levels and rate of hip bone loss in older men. J Clin Endocrinol Metab. 2009;94(8):2773-2780.

61. Nielson CM, Marshall LM, Adams AL, et al; Osteoporotic Fractures in Men Study Research Group. BMI and fracture risk in older men: the osteoporotic fractures in men study (MrOS). J Bone Miner Res. 2011;26(3):496-502.

62. Solimeo SL, Weber TJ, Gold DT. Older men's explanatory model for osteoporosis. Gerontologist. 2011;51(4):530-539.

63. Sambrook PN, Flahive J, Hooven FH, et al. Predicting fractures in an international cohort using risk factor algorithms without BMD. J Bone Miner Res. 2011;26(11):2770-2777.

64. Boonen S, Dejaeger E, Vanderschueren D, et al. Osteoporosis and osteoporotic fracture occurrence and prevention in the elderly: a geriatric perspective. Best Pract Res Clin Endocrinol Metab. 2008;22(5): 765-785.

65. Rizzoli R, Bruyere O, Cannata-Andia JB, et al. Management of osteoporosis in the elderly. Curr Med Res Opin. 2009;25(10):2373-2387.

66. Prieto-Alhambra D, Nogues X, Javaid MK, et al. An increased rate of falling leads to a rise in fracture risk in postmenopausal women with self-reported osteoarthritis: a prospective multinational cohort study (GLOW). Ann Rheum Dis. 2013;72(6):911-917.

67. Switzer JA, Jaglal S, Bogoch ER. Overcoming barriers to osteoporosis care in vulnerable elderly patients with hip fractures. J Orthop Trauma. 2009;23(6):454-459.

68. Kamatari M, Koto S, Ozawa N, et al. Factors affecting long-term compliance of osteoporotic patients with bisphosphonate treatment and QOL assessment in actual practice: alendronate and risedronate. J Bone Miner Metab. 2007;25(5):302-309.

69. Sale JE, Gignac MA, Hawker G, et al. Decision to take osteoporosis medication in patients who have had a fracture and are 'high' risk for future fracture: a qualitative study. BMC Musculoskelet Disord. 2011;12:92.

70. Haasum Y, Fastbom J, Fratiglioni L, Johnell K. Undertreatment of osteoporosis in persons with dementia? A population-based study. Osteoporos Int. 2012;23(3):1061-1068.

71. Schneider JL, Fink HA, Ewing SK, Ensrud KE, Cummings SR; Study of Osteoporotic Fractures (SOF) Research Group. The association of Parkinson's disease with bone mineral density and fracture in older women. Osteoporos Int. 2008;19(7):1093-1097.

72. Pazianas M, Cooper C, Ebetino FH, Russell RG. Long-term treatment with bisphosphonates and their safety in postmenopausal osteoporosis. Ther Clin Risk Manag. 2010;6:325-343.

73. Stevenson M, Jones ML, De Nigris E, Brewer N, Davis S, Oakley J. A systematic review and economic evaluation of alendronate, etidronate, risedronate, raloxifene and teriparatide for the prevention and treatment of postmenopausal osteoporosis. Health Technol Assess. 2005;9(22): $1-160$.

74. Díez-Pérez A, Olmos JM, Nogués X, et al. Risk factors for prediction of inadequate response to antiresorptives. $J$ Bone Miner Res. 2012;27(4):817-824.

75. Cooper C, Jakob F, Chinn C, et al. Fracture incidence and changes in quality of life in women with an inadequate clinical outcome from osteoporosis therapy: the Observational Study of Severe Osteoporosis (OSSO). Osteoporos Int. 2008;19(4):493-501.

76. Barbagallo M, Dominguez LJ, Maugeri D, et al; ICARO Study Group. Quality of life in osteoporotic women with inadequate clinical response to antiresorptive drugs: results from the ICARO study. Aging Clin Exp Res. 2007;19(Suppl 3):24-27.

77. iofbonehealth.org [homepage on the Internet]. Inadequate Responders Working Group. International Osteoporosis Foundation; [cited May 24, 2013]. Available from: http://www.iofbonehealth.org/bonehealth/ inadequate-responders-working-group. Accessed October 24, 2013.

78. Diez-Perez A, Adachi JD, Agnusdei D, et al; IOF CSA Inadequate Responders Working Group. Treatment failure in osteoporosis. Osteoporos Int. 2012;23(12):2769-2774.

79. Cutler DM, Everett W. Thinking outside the pillbox - medication adherence as a priority for health care reform. $N$ Engl J Med. 2010; 362(17):1553-1555 
80. World Health Organization. Adherence to Long-Term Therapies: Evidence for Action. Geneva: World Health Organization; 2003. Available from: http://www.who.int/chp/knowledge/publications/adherence_report/en/. Accessed May 24, 2013.

81. Cramer JA, Gold DT, Silverman SL, Lewiecki EM. A systematic review of persistence and compliance with bisphosphonates for osteoporosis. Osteoporos Int. 2007;18(8):1023-1031.

82. Sampalis JS, Adachi JD, Rampakakis E, Vaillancourt J, Karellis A, Kindundu C. Long-term impact of adherence to oral bisphosphonates on osteoporotic fracture incidence. J Bone Miner Res. 2012;27(1): 202-210.

83. Hadji P, Claus V, Ziller V, Intorcia M, Kostev K, Steinle T. GRAND: the German retrospective cohort analysis on compliance and persistence and the associated risk of fractures in osteoporotic women treated with oral bisphosphonates. Osteoporos Int. 2012;23(1):223-231.

84. Landfeldt E, Ström O, Robbins S, Borgström F. Adherence to treatment of primary osteoporosis and its association to fractures - the Swedish Adherence Register Analysis (SARA). Osteoporos Int. 2012;23(2): 433-443.

85. Lekkerkerker F, Kanis JA, Alsayed N, et al; Group for the Respect of Ethics and Excellence in Science (GREES). Adherence to treatment of osteoporosis: a need for study. Osteoporos Int. 2007;18(10):1311-1317.

86. Li L, Roddam A, Gitlin M, et al. Persistence with osteoporosis medications among postmenopausal women in the UK General Practice Research Database. Menopause. 2012;19(1):33-40.

87. Netelenbos JC, Geusens PP, Ypma G, Buijs SJ. Adherence and profile of non-persistence in patients treated for osteoporosis - a large-scale, long-term retrospective study in The Netherlands. Osteoporos Int. 2011;22(5):1537-1546.

88. Halpern R, Becker L, Iqbal SU, Kazis LE, Macarios D, Badamgarav E. The association of adherence to osteoporosis therapies with fracture, all-cause medical costs, and all-cause hospitalizations: a retrospective claims analysis of female health plan enrollees with osteoporosis. J Manag Care Pharm. 2011;17(1):25-39.

89. Landfeldt E, Lundkvist J, Ström O. The societal burden of poor persistence to treatment of osteoporosis in Sweden. Bone. 2011;48(2): 380-388.

90. Ross S, Samuels E, Gairy K, Iqbal S, Badamgarav E, Siris E. A metaanalysis of osteoporotic fracture risk with medication nonadherence. Value Health. 2011;14(4):571-581.

91. Cotté FE, Mercier F, De Pouvourville G. Relationship between compliance and persistence with osteoporosis medications and fracture risk in primary health care in France: a retrospective case-control analysis. Clin Ther. 2008;30(12):2410-2422.

92. Patrick AR, Brookhart MA, Losina E, et al. The complex relation between bisphosphonate adherence and fracture reduction. $J$ Clin Endocrinol Metab. 2010;95(7):3251-3259.

93. Siris ES, Harris ST, Rosen CJ, et al. Adherence to bisphosphonate therapy and fracture rates in osteoporotic women: relationship to vertebral and nonvertebral fractures from 2 US claims databases. Mayo Clin Proc. 2006;81(8):1013-1022.

94. Center JR, Bliuc D, Nguyen ND, Nguyen TV, Eisman JA. Osteoporosis medication and reduced mortality risk in elderly women and men. J Clin Endocrinol Metab. 2011;96(4):1006-1014.

95. Horne R, Weinman J. Patients' beliefs about prescribed medicines and their role in adherence to treatment in chronic physical illness. J Psychosom Res. 1999;47(6):555-567.

96. Horne R, Weinman J, Hankins M. The beliefs about medicines questionnaire: the development and evaluation of a new method for assessing the cognitive representation of medication. Psychol Health. 1999;14(1):1-24.

97. Siris ES, Gehlbach S, Adachi JD, et al. Failure to perceive increased risk of fracture in women 55 years and older: the Global Longitudinal Study of Osteoporosis in Women (GLOW). Osteoporos Int. 2011;22(1):27-35.

98. Solomon DH, Brookhart MA, Tsao P, et al. Predictors of very low adherence with medications for osteoporosis: towards development of a clinical prediction rule. Osteoporos Int. 2011;22(6):1737-1743.
99. Barrett-Connor E, Wade SW, Do TP, et al. Treatment satisfaction and persistence among postmenopausal women on osteoporosis medications: 12-month results from POSSIBLE US ${ }^{\mathrm{TM}}$. Osteoporos Int. 2012;23(2):733-741.

100. Penning-van Beest FJ, Goettsch WG, Erkens JA, Herings RM. Determinants of persistence with bisphosphonates: a study in women with postmenopausal osteoporosis. Clin Ther. 2006;28(2):236-242.

101. Carr AJ, Thompson PW, Cooper C. Factors associated with adherence and persistence to bisphosphonate therapy in osteoporosis: a crosssectional survey. Osteoporos Int. 2006;17(11):1638-1644.

102. Skedros JG, Holyoak JD, Pitts TC. Knowledge and opinions of orthopaedic surgeons concerning medical evaluation and treatment of patients with osteoporotic fracture. J Bone Joint Surg Am. 2006;88(1):18-24.

103. Lewiecki EM, Babbitt AM, Piziak VK, Ozturk ZE, Bone HG. Adherence to and gastrointestinal tolerability of monthly oral or quarterly intravenous ibandronate therapy in women with previous intolerance to oral bisphosphonates: a 12-month, open-label, prospective evaluation. Clin Ther. 2008;30(4):605-621.

104. Cramer JA, Lynch NO, Gaudin AF, Walker M, Cowell W. The effect of dosing frequency on compliance and persistence with bisphosphonate therapy in postmenopausal women: a comparison of studies in the United States, the United Kingdom, and France. Clin Ther. 2006;28(10):1686-1694.

105. Bartl R, Götte S, Hadji P, Hammerschmidt T. Adherence with daily and weekly administration of oral bisphosphonates for osteoporosis treatment. Dtsch Med Wochenschr. 2006;131(22):1257-1262. German.

106. Recker RR, Gallagher R, MacCosbe PE. Effect of dosing frequency on bisphosphonate medication adherence in a large longitudinal cohort of women. Mayo Clin Proc. 2005;80(7):856-861.

107. Brankin E, Walker M, Lynch N, Aspray T, Lis Y, Cowell W. The impact of dosing frequency on compliance and persistence with bisphosphonates among postmenopausal women in the UK: evidence from three databases. Curr Med Res Opin. 2006;22(7):1249-1256.

108. Penning-van Beest FJ, Erkens JA, Olson M, Herings RM. Determinants of non-compliance with bisphosphonates in women with postmenopausal osteoporosis. Curr Med Res Opin. 2008;24(5):1337-1344.

109. Lee YK, Nho JH, Ha YC, Koo KH. Persistence with intravenous zoledronate in elderly patients with osteoporosis. Osteoporos Int. 2012;23(9):2329-2333.

110. Ziller V, Kostev K, Kyvernitakis I, Boeckhoff J, Hadji P. Persistence and compliance of medications used in the treatment of osteoporosis analysis using a large scale, representative, longitudinal German database. Int J Clin Pharmacol Ther. 2012;50(5):315-322.

111. Bauer DC, Black D, Ensrud K, et al. Upper gastrointestinal tract safety profile of alendronate: the fracture intervention trial. Arch Intern Med. 2000;160(4):517-525.

112. Liberman UA. Long-term safety of bisphosphonate therapy for osteoporosis: a review of the evidence. Drugs Aging. 2006;23(4):289-298.

113. Woo C, Gao G, Wade S, Hochberg MC. Gastrointestinal side effects in postmenopausal women using osteoporosis therapy: 1-year findings in the POSSIBLE US study. Curr Med Res Opin. 2010;26(4):1003-1009.

114. Recker RR, Lewiecki EM, Miller PD, Reiffel J. Safety of bisphosphonates in the treatment of osteoporosis. Am J Med. 2009;122(Suppl 2): S22-S32.

115. Grima DT, Papaioannou A, Airia P, Ioannidis G, Adachi JD. Adverse events, bone mineral density and discontinuation associated with generic alendronate among postmenopausal women previously tolerant of brand alendronate: a retrospective cohort study. BMC Musculoskelet Disord. 2010;11:68.

116. Kanis JA, Reginster JY, Kaufman JM, et al. A reappraisal of generic bisphosphonates in osteoporosis. Osteoporos Int. 2012;23(1): 213-221.

117. Nadrash TA, Plushner SL, Delate T. Clinical pharmacists' role in improving osteoporosis treatment rates among elderly patients with untreated atraumatic fractures. Ann Pharmacother. 2008;42(3): 334-340. 
118. Giangregorio L, Dolovich L, Cranney A, et al. Osteoporosis risk perceptions among patients who have sustained a fragility fracture. Patient Educ Couns. 2009;74(2):213-220.

119. Boudou L, Gerbay B, Chopin F, Ollagnier E, Collet P, Thomas T. Management of osteoporosis in fracture liaison service associated with long-term adherence to treatment. Osteoporos Int. 2011;22(7): 2099-2106

120. Ojeda-Bruno S, Naranjo A, Francisco-Hernández F, et al. Secondary prevention program for osteoporotic fractures and long-term adherence to bisphosphonates. Osteoporos Int. 2011;22(6):1821-1828.

121. Newman ED, Matzko CK, Olenginski TP, et al. Glucocorticoid-Induced Osteoporosis Program (GIOP): a novel, comprehensive, and highly successful care program with improved outcomes at 1 year. Osteoporos Int. 2006;17(9):1428-1434.
122. Cotté FE, De Pouvourville G. Cost of non-persistence with oral bisphosphonates in post-menopausal osteoporosis treatment in France. BMC Health Serv Res. 2011;11:151.

123. Patrick AR, Schousboe JT, Losina E, Solomon DH. The economics of improving medication adherence in osteoporosis: validation and application of a simulation model. J Clin Endocrinol Metab. 2011;96(9):2762-2770.
International Journal of Women's Health

\section{Publish your work in this journal}

The International Journal of Women's Health is an international, peerreviewed open-access journal publishing original research, reports, editorials, reviews and commentaries on all aspects of women's healthcare including gynecology, obstetrics, and breast cancer. The manuscript management system is completely online and includes

\section{Dovepress}

a very quick and fair peer-review system, which is all easy to use. Visit http://www.dovepress.com/testimonials.php to read real quotes from published authors.

\footnotetext{
Submit your manuscript here: http://www.dovepress.com/international-journal-of-womens-health-journal
} 